\title{
Peningkatan Keterampilan Berbicara Siswa Melalui Model Pembelajaran Kooperatif Tipe Jigsaw Dalam Pembelajaran Bahasa Sunda
}

\author{
Yeyet \\ MTs Negeri 4 Kuningan, Indonesia \\ yeyet.mtsn4kng@gmail.com
}

\begin{abstract}
This research originated from the problem of the students' low speaking skills in Sundanese. The author tries to apply the Jigsaw Type Cooperative learning model as an effort to overcome these problems. This study aims to improve students' speaking skills in learning Sundanese. This research was conducted at MTs Negeri 4 Kuningan with the research subjects of grade $8 A$ students. This research is a classroom action research conducted in 2 gycles. The results showed an increase in students' speaking skills after implementing the Jigsaw cooperative learning model. With these results, it can be concluded that the Jigsaw cooperative model can improve the speaking skills of grade 8 A students at MTs Negeri 4 Kuningan.

Keywords: speaking skills; jigsaw type cooperative
\end{abstract}

\section{ABSTRAK}

Bahasa Sunda merupakan mata pelajaranPenelitian ini berawal dari adanya permasalahan rendahnya keterampilan berbicara siswa dalam bahasa sunda. Penulis mencoba menerapkan model pembelajaran Kooperatif Tipe Jigsaw sebagai upaya untuk mengatasi permasalahan tersebut. Penelitian ini bertujuan untuk meningkatkan keterampilan berbicara siswa dalam pembelajaran bahasa Sunda. Penelitian ini dilaksanakan di MTs Negeri 4 Kuningan dengan subyek penelitian siswa kelas 8A. Penelitian ini merupakan penelitian tindakan kelas yang dilaksanakan dalam 2 siklus. Hasil penelitian menunjukkan adanya peningkatan keterampilan berbicara siswa setelah dilaksanakan model pembelajaran Kooperatif tipe Jigsaw. Dengan hasil tersebut maka dapat disimpulkan bahwa model kooperatif tipe Jigsaw dapat meningkatkan keterampilan berbicara siswa kelas 8A di MTs Negeri 4 Kuningan.

Kata Kunci: keterampilan berbicara; kooperatif tipe jigsaw

Submitted Apr 18, 2021 | Revised May 10, 2021 | Accepted May 13, 2021

\section{Pendahuluan}

Bahasa Sunda sebagai bahasa daerah merupakan salah satu bahasa ibu bagi sebagian masyarakat Jawa Barat. Bahasa daerah juga menjadi salah satu bahasa pengantar pembelajaran di sekolah dasar di wilayah Jawa Barat (Pramswari, 2014). Bahasa Sunda sebagai bahasa daerah terbesar kedua setelah bahasa Jawa juga dapat terdesak oleh bahasa Indonesia (Krishandini, Defina, \& Wahyuni, 2019). Di sekolah dasar, bahasa Sunda diberikan sebagai mata pelajaran muatan lokal yang diberikan dalam satu minggu satu kali di wilayah Jawa Barat. Jumlah jam pelajaran yang terlalu sedikit itu sangat tidak cukup untuk memahami pembelajaran secara utuh (Wagiati, Wahya, \& Riyanto, 2017). Muatan lokal sendiri merupakan bahan kajian atau mata pelajaran pada satuan pendidikan yang berisi muatan dan proses pembelajaran tentang potensi dan keunikan lokal untuk membentuk pemahaman peserta didik terhadap keunggulan dan kearifan di daerah tempat tinggalnya (Herudin, 2017).

Pembelajaran Bahasa Sunda diarahkan untuk meningkatkan kemampuan peserta didik dalam berkomunikasi dengan menggunakan Bahasa Sunda yang baik dan benar, baik secara lisan maupun tulis, serta menumbuhkan apresiasi terhadap hasil karya kesastraan manusia Indonesia (Kushartanti, 2007; Susanti, 2015; Nurgupita, et al., 2016). Dalam komunikasi sehari-hari, orang lebih banyak menggunakan bahasa lisan dari pada tertulis. Kegiatan berbahasa lisan secara umum disebut berbicara. Keterampilan berbicara adalah salah satu aspek keterampilan berbahasa yang mempunyai empat komponen, yaitu : a) keterampilan menyimak; b) keterampilan berbicara; c) keterampilan membaca; dan d) keterampilan menulis (Halidjah, 2012; Yanti, et al., 2018; Aziza \& Muliansyah, 2020). Setiap 
keterampilan itu erat sekali hubungannya dengan tiga keterampilan lainnya. Dalam mempelajari keterampilan berbahasa, biasanya dilaksanakan melalui suatu hubungan urutan yang teratur. Mula-mula pada masa kecil belajar menyimak bahasa, berbicara, sesudah itu belajar membaca dan menulis. Keempat keterampilan tersebut pada diri manusia merupakan satu kesatuan (Tarigan, et al., 1997).

Menurut Tarigan, et al. (1997), berbicara adalah keterampilan menyampaikan pesan melalui bahasa lisan. Kaitan antara pesan dan bahasa lisan sebagai media penyampaian sangat erat. Pesan yang diterima oleh pendengar tidaklah dalam wujud asli, tetapi dalam bentuk bunyi bahasa. Kemampuan berbicara memberi makna yang penting untuk berkomunikasi dalam kehidupan sehari-hari. Manusia dapat mengalami perkembangan karena melakukan kontak bicara dengan orang lain.

Menurut hasil wawancara penulis dengan guru Bahasa Sunda ternyata hasil belajar siswa kelas 8 A MTs Negeri 4 Kuningan Kabupaten Kuningan dalam berbicara masih rendah. Siswa masih merasa kesulitan dalam berbagai hal, antara lain : 1) menjawab pertanyaan guru walaupun pertanyaan yang diajukan berhubungan dengan keadaan atau kegiatan siswa sehari-hari, 2) mengajukan pertanyaan dalam situasi pembelajaran, rapat kelas, rapat OSIS dan sebagainya, 3) menceritakan kembali isi suatu bacaan, 4) menyanggah pendapat orang lain, 5) membawakan pidato dihadapan teman sekelasnya, 6) mengumumkan sesuatu kepada teman (berkaitan dengan kegiatan ke-OSIS-an), dan 7) kegiatan berbicara lainnya.

Pada umumnya siswa kelas 8 A MTs Negeri 4 Kuningan Kabupaten Kuningan masih merasa malu dan belum mempunyai keberanian untuk mengungkapkan idenya melalui berbicara. Dari kegiatan wawancara yang penulis lakukan dengan guru mata pelajaran Bahasa Sunda kelas 8 A MTs Negeri 4 Kuningan Kabupaten Kuningan, beliau menjelaskan bahwa dari jumlah sekitar 33 Siswa setiap kelasnya hanya dua atau tiga siswa yang berani bertanya. Pertanyaan yang diajukan juga biasanya merupakan kalimat-kalimat sederhana. Selain itu, pada berbicara secara formal hanya beberapa siswa dari ratusan siswa MTs N 4 Kuningan Kabupaten Kuningan yang mau atau mampu melakukannya, misalnya dalam rapat OSIS atau pidato pada acara perpisahan kelas IX.

Untuk meningkatkan keterampilan berbicara siswa, maka guru harus mampu menciptakan proses belajar mengajar dengan strategi pembelajaran yang tepat. Selain itu, juga harus mampu membangkitkan motivasi siswa untuk mengikuti pelajaran Bahasa Sunda. Dalam memilih srategi pembelajaran, guru hendaknya dapat memilih, menyesuaikan, dan mengembangkan strategi pembelajaran dengan tepat, sehingga dapat mengantarkan siswa mencapai kompetensi yang akan dicapai (Abidin, 2019). Pemilihan strategi atau model pembelajaran yang tepat merupakan hal penting yang perlu dipikirkan oleh guru, agar mampu membuat siswa lebih aktif dan produktif. Model pembelajaran kooperatif tipe jigsaw merupakan sebuah model pembelajaran yang dapat dijadikan sebuah alternatif.

Pendekatan kooperatif merupakan suatu pendekatan yang mengutamakan adanya kerja sama, yakni kerja sama antarsiswa dalam kelompok untuk mencapai tujuan pembelajaran (Amiruddin, 2019; Rahman, et al., 2019). Menurut Nurhadi \& Senduk (2003:60), pembelajaran kooperatif adalah pembelajaran yang secara sadar dan sengaja mengembangkan interaksi yang silih asuh untuk menghindari ketersinggungan dan kesalahpahaman yang dapat menimbulkan permusuhan. Tujuan pembelajaran kooperatif adalah untuk membangkitkan interaksi yang efektif di antara anggota kelompok melalui diskusi. Dalam hal ini sebagian besar aktivitas pembelajaran berpusat pada siswa, yakni mempelajari materi pelajaran, berdiskusi untuk memecahkan masalah (tugas). Dengan interaksi yang efektif dimungkinkan semua kelompok dapat menguasai materi pada tingkat yang relatif sejajar.

Salah satu tipe dalam model pembelajaran kooperatif adalah jigsaw. Jigsaw telah dikembangkan dan diujicoba oleh Elliot Aronson dan teman-teman di Universitas Texas, kemudian diadaptasi oleh Slavin dan teman-teman di Universitas John Hopkins (Ibrahim, et al., 2000). Pembelajaran kooperatif tipe jigsaw adalah suatu tipe pembelajaran kooperatif yang terdiri atas beberapa anggota dalam satu 
kelompok yang bertanggung jawab atas penguasaan bagian materi belajar dan mampu mengajarkan bagian tersebut kepada anggota kelompoknya (Arends, 2007).

Dengan tipe ini, guru memperhatikan skemata atau latar belakang pengalaman siswa dan membantu siswa mengaktifkan skemata ini agar bahan pelajaran menjadi lebih bermakna (Lie, 2005). Pembelajaran kooperatif tipe jigsaw dapat meningkatkan rasa tanggung jawab antarsiswa. Siswa tidak hanya mempelajari bagian akademik yang ditugaskan oleh guru, tetapi juga harus siap memberikan dan menjelaskan bagian tersebut kepada siswa yang lainnya dalam satu kelompok. Dengan demikian siswa saling tergantung satu dengan yang lain dan bekerja sama secara kooperatif dalam kelompok.

Pembelajaran dengan menggunakan model pembelajaran kooperatif tipe jigsaw diharapkan agar siswa dapat lebih meningkatkan keterampilan berbicara siswa, khususnya dalam menyampaikan laporan perjalanan. Selain itu, pembelajaran ini juga mampu mengaktifkan siswa untuk belajar bekerja sama. Di dalam proses belajar, tidak ada siswa yang hanya sebagai pendengar saja karena setiap siswa mempunyai tanggung jawab masing-masing pada bagian-bagian materi yang dipelajari agar pembelajaran dapat tuntas.

Usaha untuk meningkatkan keterampilan berbicara memerlukan strategi/model pembelajaran yang efektif dan efisien. Penggunaan model pembelajaran kooperatif tipe jigsaw diharapkan dapat membangkitkan motivasi siswa untuk belajar serta meningkatkan keterampilan siswa kelas 8 A MTs Negeri 4 Kuningan Kabupaten Kuningan dalam berbicara.

\section{Metode Penelitian}

Jenis penelitian ini adalah Penelitian Tindakan Kelas (PTK). Penelitian ini sifatnya berbasis kelas yang melibatkan komponen yang ada di dalam kelas, yaitu siswa, guru, materi pelajaran, dan teknik pembelajaran yang terangkum dalam proses belajar mengajar di dalam kelas.

Tujuan penelitian ini adalah memperbaiki pembelajaran untuk meningkatkan hasil belajar siswa secara maksimal. Dalam hal ini, memperbaiki pembelajaran berbicara dan meningkatkan kompetensi menyampaikan laporan perjalanan yang ditempuh melalui model pembelajaran kooperatif tipe jigsaw.

Penelitian ini dilakukan dalam dua siklus, yaitu siklus I dan siklus II. Setiap siklus terdiri atas empat tahap, yaitu perencanaan, tindakan, pengamatan, dan refleksi.

Subjek penelitian tindakan kelas ini adalah kompetensi menyampaikan laporan perjalanan siswa kelas VIII. Adapun sumber datanya adalah kelas 8 A MTs Negeri 4 Kuningan Kabupaten Kuningan. Penentuan siswa kelas $8 \mathrm{~A}$ sebagai subjek penelitian didasarkan atas pertimbangan sebagai berikut: (1) sesuai Kurikulum 2013, pembelajaran Bahasa Sunda SMP dan MTs, salah satu kompetensi dasar yang harus dicapai siswa kelas VIII adalah siswa mampu menyampaikan laporan secara lisan dengan bahasa yang baik dan benar; (2) berdasarkan informasi dari guru mata pelajaran Bahasa Sunda, siswa kelas VIII a memiliki kemampuan akademik relatif rendah, khususnya dalam keterampilan berbicara.

Teknik pengumpulan data dalam penelitian ini menggunakan teknik tes dan teknik nontes. Teknik tes digunakan untuk memperoleh gambaran hasil pembelajaran menyampaikan laporan perjalanan melalui pembelajaran kooperatif tipe jigsaw. Data melalui teknik non tes dilakukan dengan data observasi, wawancara, jurnal, sosiometri, dan dokumentasi kegiatan pembelajaran. Untuk mengetahui tingkat kemampuan siswa dalam berbicara khususnya menyampaikan laporan perjalanan, diperlukan alat ukur yang berupa tes perbuatan. Tes perbuatan ini berupa tampilan kompetensi siswa yang menyampaikan laporan perjalanan. Aspek yang dinilai dalam tes ini antara lain : (1) kelengkapan informasi; (2) ketepatan struktur kalimat; (3) kelancaran; (4) gaya pengucapan; (5) kenyaringan suara; (6); pemilihan kata dan ungkapan (diksi) dan (7) ketepatan jeda dan intonasi. Instrumen non tes yang digunakan dalam penelitian ini adalah lembar observasi, pedoman wawancara, jurnal, sosiometri dan dokumentasi kegiatan pembelajaran.

Dalam penelitian tindakan kelas ini, peneliti menggunakan teknik analisis data yang dilakukan secara kuantitatif dan secara kualitatif. Teknik kuantitatif dipakai untuk menganalisis data kuantitatif. 
Data kuantitatif ini diperoleh dari hasil tes menyampaikan laporan perjalanan melalui pembelajaran kooperatif tipe jigsaw pada siklus I dan siklus II. Analisis hasil tes secara kuantitatif dihitung secara persentase. Teknik kualitatif digunakan untuk menganalisis hasil dari data nontes yang diperoleh, yaitu data observasi, wawancara, jurnal, sosiometri, dan dokumentasi.

\section{Hasil dan Pembahasan}

Hasil penelitian ini memaparkan peningkatan keterampilan menyampaikan laporan perjalanan setelah mengikuti kegiatan pembelajaran siklus I dan siklus II. Tindakan pada siklus I dan siklus II berupa pembelajaran keterampilan menyampaikan laporan perjalanan melalui pembelajaran kooperatif tipe jigsaw. Pengambilan data dilakukan melalui tes dan nontes.

1. Peningkatan Keterampilan Menyampaikan Laporan Perjalanan

Hasil penelitian menunjukkan bahwa keterampilan menyampaikan laporan perjalanan siswa kelas 8 A MTs Negeri 4 Kuningan Kabupaten Kuningan mengalami peningkatan yang cukup berarti. Peningkatan tersebut tampak pada tahapan penelitian tindakan kelas, yaitu siklus I, dan siklus II. Untuk memberikan deskripsi yang lebih jelas mengenai peningkatan rata-rata skor nilai setiap aspek penilaian maka ditunjukkan hasil tes keterampilan menyampaikan laporan perjalanan pada tabel 1.

Tabel 1. Peningkatan Keterampilan Menyampaikan Laporan Perjalanan

\begin{tabular}{clccc}
\hline \multirow{2}{*}{ No Aspek Penilaian } & \multicolumn{2}{c}{ Nilai Rata-rata Aspek } & Peningkatan (\%) \\
& SI & SII & SI-SII \\
\hline 1. Kelengkapan informasi & 4,25 & 4,9 & 15,29 \\
2. Ketepatan struktur kalimat & 2,525 & 3,275 & 29,70 \\
3. Kelancaran & 2,675 & 3,175 & 18,69 \\
4. & Pemilihan kata dan ungkapan (diksi) & 2,55 & 3,25 & 27,45 \\
5. Jeda dan intonasi & 2,575 & 3,15 & 22,33 \\
6. Gaya pengucapan & 2,5 & 3,125 & 25,00 \\
7. & Kenyaringan suara & 2,525 & 3,075 & 21,78 \\
Nilai & Rata-rata Kelas & 65,33 & 79,83 & 22,20 \\
\hline
\end{tabular}

Pada data tabel 44 menunjukkan bahwa hasil. Nilai rata-rata tersebut berasal dari jumlah rata-rata setiap aspek yang dinilai. Pada tes siklus I nilai rata-rata keterampilan menyampaikan laporan perjalanan siswa kelas 8 A MTs Negeri 4 Kuningan Kabupaten Kuningan mencapai nilai rata-rata 65,33 masuk pada kategori cukup, berada pada rentang nilai 60-74. Meskipun demikian, hasil yang dicapai pada siklus I ini belum memenuhi target yang telah ditetapkan, yaitu 70 .

Penyebab masih rendahnya nilai siswa kelas 8 A MTs Negeri 4 Kuningan Kabupaten Kuningan dalam tes menyampaikan laporan perjalanan pada siklus I, dikarenakan pembelajaran kooperatif tipe jigsaw yang diterapkan masih dirasakan baru oleh siswa. Cara pembelajaran seperti ini merupakan proses awal bagi siswa untuk menyesuaikan diri dalam belajar.

Pada aspek kelengkapan informasi siswa mencapai nilai 4,25. Itu artinya kemampuan siswa dalam mengumpulkan informasi yang dibutuhkan sudah baik. Nilai rata-rata siswa pada aspek kelancaran $(2,675)$, pemilihan kata dan ungkapan (diksi) $(2,55)$, penjedaan dan intonasi $(2,575)$, ketepatan struktur kalimat $(2,525)$, dan kenyaringan suara $(2,525)$ berada dalam skala baik. Sedangkan nilai rata-rata siswa pada aspek gaya pengucapan masih rendah yaitu $(2,5)$ berada dalam skala cukup. Jika dibandingkan enam aspek lain, nilai aspek gaya pengucapan adalah yang paling rendah. Itu artinya siswa masih merasa kesulitan dalam berekspresi di depan kelas, sehingga masih diperlukan latihan intensif lagi bagi siswa. Hasil tes pada siklus I ini dirasa kurang memuaskan, oleh karena itu, perlu diadakan tes lagi pada siklus II supaya hasilnya lebih baik. 
Hasil tes siklus II nilai rata-rata siswa kelas 8 A MTs Negeri 4 Kuningan Kabupaten Kuningan mencapai 79,83 atau sudah berada dalam kategori baik, berada pada rentang nilai 75-84. Dengan demikian nilai rata-rata siklus II sudah memenuhi target yang ditentukkan, yaitu 70. Nilai rata-rata pada setiap aspek siklus II secara keseluruhan mengalami peningkatan yang cukup berarti. Hal ini karena pada siklus II perilaku siswa saat mengikuti proses pembelajaran keterampilan menyampaikan laporan perjalanan sudah mengalami perubahan yang signifikan dengan pembelajaran menyampaikan laporan perjalanan melalui pembelajaran kooperatif tipe jigsaw. Hal itu tampak pada peningkatan nilai rata-rata siklus II dari siklus I adalah 22,20\%.

Dari tujuh aspek penilaian, enam aspek masuk dalam kategori baik. Aspek ketepatan struktur kalimat $(3,275)$, aspek kelancaran $(3,175)$, aspek pemilihan kata dan ungkapan (diksi) $(3,25)$, aspek jeda dan intonasi $(3,15)$, aspek gaya pengucapan $(3,125)$, dan aspek kenyaringan suara $(3,075)$ masuk dalam kategori baik. Sedangkan aspek kelengkapan informasi masuk dalam kategori sangat baik dengan nilai rata-rata siswa $(4,9)$. Dengan demikian dapat dikatakan secara keseluruhan siswa kelas 8 A MTs Negeri 4 Kuningan Kabupaten Kuningan sudah mampu menyampaikan laporan perjalanan melalui pembelajaran kooperatif tipe jigsaw.

Berdasarkan deskripsi pembahasan di atas dapat dibuktikan bahwa pembelajaran menyampaikan laporan perjalanan melalui pembelajaran kooperatif tipe jigsaw dapat meningkatkan kemampuan berbicara siswa kelas 8 A MTs Negeri 4 Kuningan Kabupaten Kuningan khususnya dalam pembelajaran menyampaikan laporan perjalanan.

2. Perubahan Perilaku Siswa dalam Pembelajaran Kooperatif Tipe Jigsaw

Berdasarkan hasil nontes siklus I yang diperoleh melalui observasi, jurnal, sosiometri, dan wawancara diketahui kesiapan siswa mengikuti pembelajaran keterampilan menyampaikan laporan perjalanan melalui pembelajaran kooperatif tipe jigsaw belum sepenuhnya terfokus. Selama pembelajaran berlangsung, tidak semua siswa mengikutinya dengan baik. Peneliti menyadari hal tersebut, karena pola pembelajaran yang diterapkan peneliti merupakan hal baru bagi mereka, sehingga perlu proses untuk menyesuaikannya.

Pada siklus II, siswa mengalami perubahan perilaku yang lebih baik. Hal ini dapat diketahui dari perilaku siswa yang sebelumnya tidak mengikuti pembelajaran dengan baik pada siklus I. Pada siklus II ini mereka mulai melaksanakan kegiatan pembelajaran yang diterapkan peneliti dengan baik. Hal ini menunjukkan bahwa mereka sudah mampu menyesuaikan diri dengan model pembelajaran kooperatif tipe jigsaw yang peneliti terapkan dalam pembelajaran menyampaikan laporan perjalanan. Siswa terlihat mulai merespon positif pembelajaran menyampaikan laporan perjalanan melalui model pembelajaran kooperatif tipe jigsaw. Hasil observasi pada siklus I dan siklus II tampak secara lebih jelas pada tabel 2.

Tabel 2. Perbandingan Hasil Observasi Siklus I dan Siklus II

\begin{tabular}{clcc}
\hline \multirow{2}{*}{ No. } & Aspek yang Diamati & \multicolumn{2}{c}{ Hasil Observasi } \\
\hline 1 & $\begin{array}{l}\text { Respon pertama siswa saat pertama kali guru menginformasikan } \\
\text { kegiatan pembelajaran menyampaikan laporan perjalanan melalui }\end{array}$ & C & B \\
& $\begin{array}{l}\text { pembelajaran kooperatif tipe jigsaw } \\
2\end{array}$ & Keaktivan siswa dalam mencari materi dalam kelompok ahli & \\
3 & $\begin{array}{l}\text { Keaktifan siswa mendiskusikan materi laporan perjalanan dalam } \\
\text { kelompok ahli }\end{array}$ & B & A \\
4 & $\begin{array}{l}\text { Keberanian dan antusias siswa untuk berlatih menyampaikan materi } \\
\text { laporan perjalanan yang dikuasainya dalam kelompok asal }\end{array}$ & D & B \\
5 & $\begin{array}{l}\text { Antusias siswa mendengarkan temannya berbicara } \\
\text { Keaktivan siswa memberi tanggapan terhadap berbicaratemannya }\end{array}$ & B & B \\
7 & Sikap menerima tanggapan dari teman & B & B \\
8 & Respon siswa dalam mengikuti pembelajaran menyampaikan laporan & C & B \\
\hline
\end{tabular}


perjalanan melalui pembelajaran kooperatif tipe jigsaw.

Berdasarkan tabel 2, respon pertama siswa saat guru menginformasikan kegiatan menyampaikan laporan perjalanan terlihat biasa-biasa saja. Saat peneliti menanyakan tentang materi dalam laporan perjalanan pada masing-masing siswa, kebanyakan siswa masih merasa malu untuk menyebutkannya. Mereka takut kalau diminta berbicara di depan kelas, sehingga mereka terlihat kurang aktif di awal pembelajaran.

Berbeda dengan kondisi pembelajaran pada siklus II di mana siswa terlihat lebih aktif dan lebih antusias untuk menerima pelajaran. Siswa terlihat kurang puas terhadap hasil tes menyampaikan laporan perjalanan pada saat siklus I, sehingga siswa bersemangat untuk memperbaikinya. Pada siklus II ini siswa lebih berani untuk menanyakan tentang cara berbicara yang baik pada peneliti. Mereka tanpa malu-malu juga mengakui kelemahannya saat berbicara dan menanyakan bagaimana cara mengatasinya.

Selanjutnya, saat siswa bergabung dalam kelompok ahli, pada siklus I siswa sudah terlihat cukup aktif dalam mencari materi yang akan mereka ungkapkan dalam tes menyampaikan laporan perjalanan. Namun, ada pula beberapa siswa yang bercanda dalam kelompok sehingga agak mengganggu teman lain yang sedang berdiskusi. Kondisi ini sudah tidak terlihat dalam siklus II. Siswa terlihat aktif dalam mencari materi yang akan mereka ungkapkan dalam tes menyampaikan laporan perjalanan pada siklus II. Mereka bahkan sudah mempersiapkannya dari rumah sehingga siswa terlihat lebih tenang dan tidak bingung dalam mencari materi yang akan mereka ungkapkan dalam berbicara. Seperti pada kelompok ahli dalam siklus I, kelompok ahli dalam siklus II ini juga berdiskusi mencari waktu-waktu penting dalam laporan perjalanan, peristiwa-peristiwa penting dalam laporan perjalanan, tempat-tempat penting dalam laporan perjalanan, dan peserta, sarana juga kelengkapan dalam laporan perjalanan.

Pada siklus I, keberanian dan antusias siswa untuk berlatih berbicara dalam kelompok sangat kurang. Ada yang berlatih dengan giat, namun kebanyakan siswa masih malu-malu dalam berlatih berbicara dalam kelompok asalnya. Mereka juga membutuhkan waktu yang lama untuk menemukan kelompok asal mereka setelah kembali dari kelompok ahli. Berbeda dengan saat siklus I, pada siklus II ini siswa lebih cepat menemukan kelompoknya. Dalam kelompok asal ini mereka terlihat lebih antusias dan lebih berani berlatih berbicara menyampaikan laporan perjalanan. Saat siswa berlatih berbicara, peneliti mengamati kegiatan tersebut dan peneliti juga memberikan beberapa masukan mengenai gaya berbicara siswa.

Pada saat siswa berbicara menyampaikan laporan perjalanan, baik dalam siklus I maupun siklus II siswa lain cukup antusias untuk mendengarkannya. Hal ini terlihat saat salah seorang siswa selesai berbicara, siswa yang lain memberikan tanggapan mengenai kekurangan dan kelebihan temannya agar nantinya dapat memperbaiki kekurangannya tersebut dan dapat berbicara lebih baik lagi. Siswa yang diberi tanggapan terlihat senang menerima masukan dari teman sekelompoknya. Mereka berterima kasih atas kritik yang diberikan dan memberikan alasan tentang kekurangannya pada saat dia berbicara menyampaikan laporan perjalanan.

Respon siswa dalam mengikuti pembelajaran menyampaikan laporan perjalanan melalui pembelajaran kooperatif tipe jigsaw pada siklus II ini dapat dikatakan baik. Siswa bersemangat dalam mengikuti pembelajaran dari awal hingga akhir. Siswa tidak lagi terlihat malu-malu di awal pembelajaran seperti pada saat siklus I. Siswa terlihat antusias dalam mengikuti setiap kegiatan pembelajaran. Mereka juga dengan cepat dapat menempatkan diri dalam kelompok asal maupun kelompok ahli. Ketika mereka berkelompok mencari materi dalam laporan perjalanan, mereka terlihat lebih aktif, dan mereka juga mendiskusikannya dalam kelompok ahli. Dalam kelompok asal mereka juga terlihat bersemangat dalam berlatih berbicara menyampaikan materi bagiannya. Mereka saling berkomentar mengenai gaya berbicara temannya sehingga kelas terlihat lebih hidup dibanding pada saat siklus I. 
Hasil jurnal dan wawancara pada siklus I maupun siklus II memperlihatkan bahwa pada umumnya siswa menyatakan senang saat mengikuti pembelajaran menyampaikan laporan perjalanan melalui pembelajaran kooperatif tipe jigsaw. Hasil jurnal menunjukkan sebagian besar siswa merasa senang dan tertarik untuk mengikuti pembelajaran ini karena dapat menambah pengetahuan. Namun, masih ada siswa yang mengatakan pembelajaran ini baru mereka alami, dan mereka merasa senang melihat cara berbicara teman-teman mereka. Selanjutnya, saat ditanya mengenai perlunya kerja kelompok dalam pembelajaran ini, sebagian besar siswa mengatakan sangat setuju. Mereka berpendapat dengan adanya kelompok ini mereka dapat berlatih berbicara dengan lebih santai. Mereka juga mengatakan senang dengan adanya kelompok ini karena mereka bisa saling bekerjasama dan saling membantu dengan teman mengenai cara berbicara dan berekspresi yang baik.

Hasil wawancara yang telah dilakukan juga menyatakan bahwa siswa tertarik dengan pembelajaran menyampaikan laporan perjalanan melalui pembelajaran kooperatif tipe jigsaw. Mereka kadang mengalami kesulitan dalam menuangkan gagasannya dalam bentuk berbicara di depan umum. Hal ini disebabkan oleh kurang terbiasanya mereka dalam menyampaikan laporan perjalanan di depan umum dan kurang latihan. Ada juga siswa yang tidak mengalami kesulitan yang cukup berarti.

Dengan adanya pembelajaran kooperatif tipe jigsaw dalam pembelajaran menyampaikan laporan perjalanan dapat membantu siswa mengatasi kesulitan tersebut karena selain dalam pembelajaran dituntut untuk sering berlatih, pembelajaran dengan tipe jigsaw ini dapat memperlancar siswa saat berbicara di depan umum dan sangat menarik. Alasan lain yang membuat siswa tertarik adalah mereka merasa senang dapat bekerjasama dengan teman-temannya dalam kelompok, mereka senang dapat saling membantu dan mencari pemecahan masalah dengan suasana nyaman dan tidak canggung dalam mendiskusikan masalah-masalahnya. Dalam pembelajaran ini siswa juga dituntut untuk berpikir kritis untuk mendapatkan pengetahuan baru serta siswa dipancing kekreativitasannya dalam berbicara.

Berdasarkan hasil analisis terhadap data sosiometri dapat ditemukan adanya perubahan perilaku siswa. Pada siklus I masih ada beberapa anggota kelompok yang kurang aktif dalam kelompok. Hal ini karena siswa tersebut tidak mau berkelompok dengan baik, bergurau dengan anggota kelompok lain, sehingga teman sekelompoknya mengasingkannya. Namun, pada siklus II tidak ada lagi siswa yang pasif dalam kelompoknya. Perbaikan yang peneliti lakukan dalam siklus II adalah memperbaiki posisi tiap kelompok pada siklus II. Selain itu siswa juga diberi pancingan berupa hadiah yang diberikan pada kelompok terbaik dan pembicara terbaik. Hal inilah yang membuat siswa termotivasi untuk bisa menjadi yang terbaik.

Perubahan perilaku siswa dan peningkatan kompetensi menyampaikan laporan perjalanan siswa ini merupakan sesuatu yang menggembirakan bagi peneliti. Sebelum dilaksanakannya tindakan siklus II, ada sebagian siswa yang berperilaku negatif selama proses pembelajaran dan kompetensi menyampaikan laporan perjalanan siswa juga masih rendah. Kemudian, setelah dilaksanakan tindakan perbaikan pembelajaran menyampaikan laporan perjalanan melalui pembelajaran kooperatif tipe jigsaw pada siklus II, perilaku siswa berubah ke arah positif dan kompetensi menyampaikan laporan perjalanan siswa mengalami peningkatan. Dengan demikian dapat disimpulkan bahwa penerapan pembelajaran kooperatif tipe jigsaw dalam pembelajaran menyampaikan laporan perjalanan mampu merubah perilaku siswa ke arah yang positif dan mampu meningkatkan kompetensi siswa dalam menyampaikan laporan perjalanan.

\section{Kesimpulan}

Berdasarkan data hasil penelitian yang telah dilaksanakan dapat diambil simpulan bahwa ada peningkatan keterampilan menyampaikan laporan perjalanan pada siswa kelas VIII D SMP Negeri 1 Jamblang, setelah dilaksanakan penelitian dengan menggunakan model pembelajaran kooperatif tipe jigsaw. Di samping itu, ada perubahan positif dari perilaku belajar siswa terhadap proses pembelajaran keterampilan menyampaikan laporan perjalanan melalui pembelajaran kooperatif tipe jigsaw. 
Perubahan tersebut terlihat dari perbandingan hasil observasi siklus I dan siklus II yang menunjukkan perubahan perilaku belajar siswa yang semakin positif. Sebagian besar siswa merasa senang dan tertarik dengan pembelajaran yang dilaksanakan. Selain itu, siswa juga merespon positif terhadap model pembelajaran kooperatif tipe jigsaw yang digunakan oleh guru. Hal ini dapat dilihat dari hasil nontes siklus I dan siklus II.

\section{Daftar Pustaka}

Abidin, A. M. (2019). Kreativitas Guru Menggunakan Model Pembelajaran dalam Meningkatkan Hasil Belajar Siswa. Didaktika: Jurnal Kependidikan, 11(2), 225-238.

Amiruddin, A. (2019). Pembelajaran kooperatif dan kolaboratif. Journal of Education Science, 5(1).

Arends, Richard. (2007). Learning to Teach. Yogykarta: Pustaka Pelajar.

Aziza, L. F., \& Muliansyah, A. (2020). Keterampilan Berbahasa Arab Dengan Pendekatan Komprehensif. El-Tsaqafah: Jurnal Jurusan PBA, 19(1), 56-71.

Halidjah, S. (2012). Evaluasi keterampilan berbicara dalam pembelajaran Bahasa Indonesia. Jumal Visi Ilmu Pendidikan, 2(1).

Herudin, D. (2017). Pengembangan Bahasa Daerah (Sunda) melalui Pembinaan Kegiatan Apresiasi Babsa dan Seni di Jawa Barat. Proseding Konferensi Bahasa Daerah FPBS UPI Etika dalam Budaya, Bahasa, Sastra, dan Seni Daerah sebagai Pembentukan Jati Diri Bangsa, hlm. 1-7. Bandung: FPBS UPI

Ibrahim, M. Rachmadiarti, F., Nur, M. \& Ismono. (2002). Pembelajaran kooperatif. Surabaya : Universitas Press kampus UNESA.

Krishandini, Defina, \& Wahyuni, E. S. (2019). A potrait of sundanese maintenance in multilingual learnig in Bogor. LITERA, 18(2), 262-274. doi:10.21831/ltr.v18i2.19077.

Kushartanti, K. (2007). Strategi pembelajaran bahasa dan sastra Indonesia di sekolah dasar: Peran guru dalam menyikapi kurikulum tingkat satuan pendidikan. Wacana, 9(1), 107-117.

Lie, A. (2005). Cooperative Learning Mempraktikekan Cooperative Learning di Ruang-Ruang Kelas. Jakarta : PT Gramedia Widiasarana Indonesia.

Nurgupita, S., Irawati, R., \& Iswara, P. D. (2016). Penerapan Metode Pqrst (Preview, Question, Read, Sumary, Test) Dengan Teknik Permainan Amplop Warna Dalam Meningkatkan Kemampuan Menyimpulkan Isi Cerita Anak. Jurnal Pena Ilmiah, 1(1), 1041-1050.

Nurhadi \& Senduk, A. G. (2003). Pembelajaran Kontekstual dan Penerapannya dalam KBK. Malang: Universitas Negeri Semarang.

Pramswari, L. P. (2014). Pembelajaran bahasa sunda di wilayah perbatasan: Dilema implementasi kurikulum 2013. Mimbar Sekolah Dasar, 1(2), 201-208. doi:10.17509/mimbar-sd.v1i2.884.

Rahman, N., Hasyim, A., \& Jalil, M. (2019). Perbandingan Model Pembelajaran Kooperatif Tipe Examples Non Examples Dan Tipe Number Head Together Terhadap Hasil Belajar Pada Mata Pelajaran Ekonomi Kelas X Ilmu-Ilmu Sosial Sma Negeri 4 Takalar. Jurnal Ilmiab Pena: Sains dan Ilmu Pendidikan, 11(1), 20-30.

Susanti, R. D. (2015). Pembelajaran Apresisasi Sastra di Sekolah Dasar. ELEMENTARY: Islamic Teacher Journal, 3(1).

Tarigan, H. G. (1997). Pengajaran Analisis Berbahasa. Bandung: Angkasa.

Wagiati., Wahya, \& Riyanto, S. (2017). Vitalitas bahasa Sunda di Kabupaten Bandung. LITERA, 16(2), 309-317. doi:10.21831/ltr.v16i2.14357

Yanti, N., Suhartono, S., \& Kurniawan, R. (2018). Penguasaan Materi Pembelajaran Keterampilan Berbahasa Indonesia Mahasiswa S1 Program Studi Pendidikan Bahasa Dan Sastra Indonesia Fkip Universitas Bengkulu. Jurnal Ilmiah KORPUS, 2(1), 72-82. 